\title{
BOTTOM DEPOSITS AND SEDIMENTATION IN NORTHERN AIRISTO IN SOUTHWESTERN FINLAND
}

\author{
Aarre Heino
}

Heino Aarre 1973: Bottom deposits and sedimentation in northern Airisto in Southwestern Finland. Bull. Geol. Soc. Finland 45. 131-142.

The sediments of the latest sea-phases, Litorina and Postlitorina, which together are called Litorina in this paper, could be easily distinguished almost everywhere from those of the earlier lake-phase, Ancylus, on the basis of the water content, the organic matter content, the grain size, and the diatoms.

On the basis of the quality of bottom surface sediments, areas of erosion and accumulation can be roughly separated from each other. Wave action is at present the most important eroding factor in the examined area, but stream channels can also be seen.

Aarre Heino, Departement of Geography, University of Turku, 20500 Turku 50, Finland, or Archipelago Research Institute, University of Turku, Seili, 21660 Nawv, Finland.

\section{Introduction}

The sedimentation of the Baltic Sea differs clearly from that of the oceans. Areas of most intensive sedimentation in the Baltic Sea are usually found in the middle parts and in the deep basins, where currents and wave action are not effective. In the oceans sedimentation is most intensive along the front of the continental shelf (Bordowskiy 1965, p. 44).

In the Baltic Sea the average annual rate of sedimentation in areas of deep water can be as much as $2 \mathrm{~mm}$, per year (Ignatius 1958a, p. 39). For instance, in the Gotland Deep the rate of sedimentation has been estimated to be about $1 \mathrm{~mm}$. per year (Ignatius et al 1971, p. 76). In the archipelago of the southwest of Finland sedimentation has, in addition, special features of its own ( $c f$. Winterhalter 1972, p. 51-52). In the examined area conditions have been further changed through the agency of man, who has transported dredged clay from the port of Turku to this area.

The investigated area is situated in SW-Finland, and comprises the northern parts of an open stretch of the sea, known as Airisto, which lies SW of Turku (Fig. 1). A characteristic feature of the whole of Airisto is a network of steep-walled fracture lines, which have formed the present landscape of the archipelago with typical straight sounds and steep-walled islands.

During and after deglaciation this area, broken by fractures, was covered with glacial and 


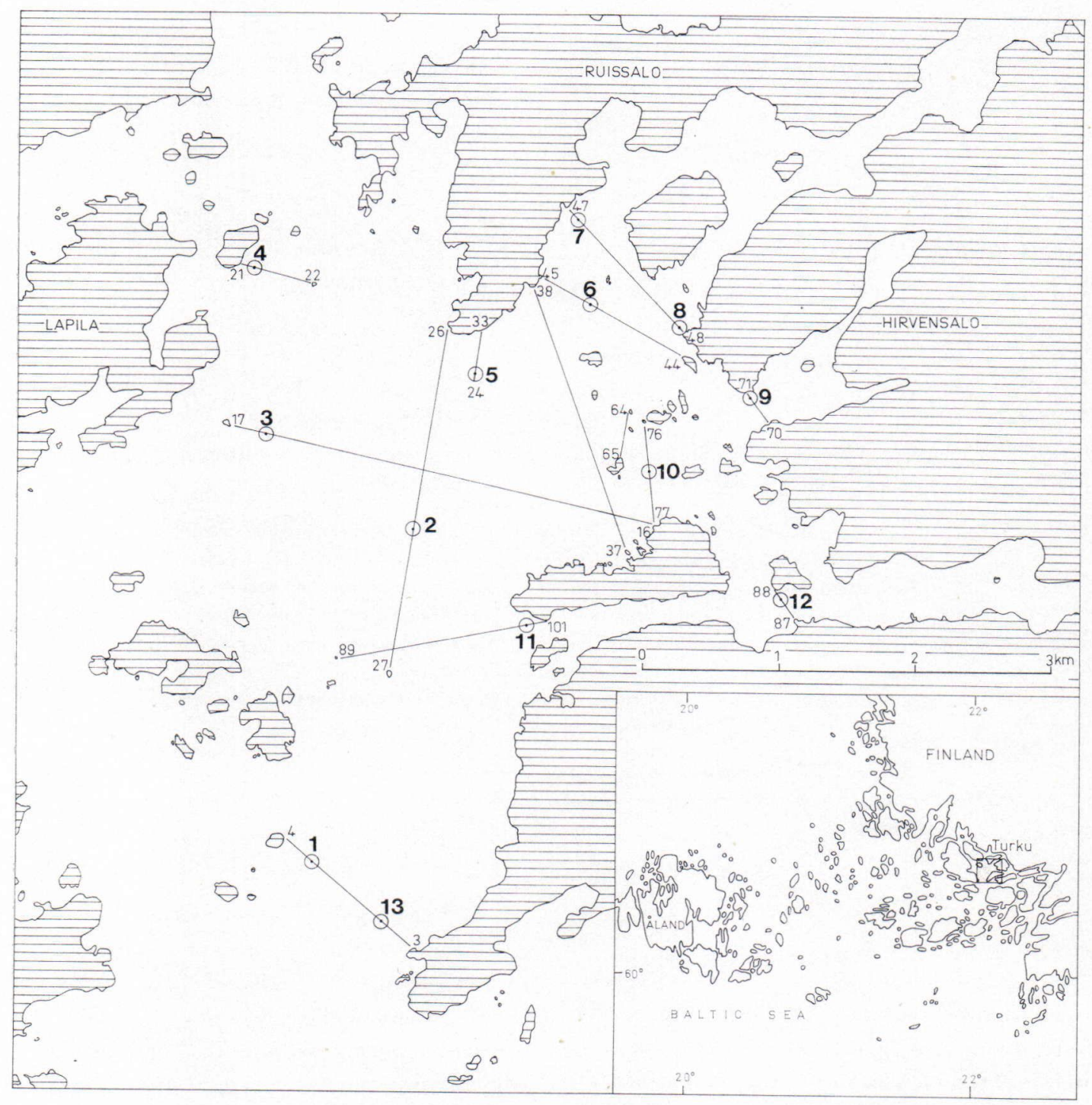

FIG. 1. The investigated area, most important sounding lines and sampling points.

postglacial sediments (Fig. 2). When the Litorina sea was at its maximum, about 7000 years ago, the sea level in the investigated area lay about 50 metres higher than now (Hyyppä 1966). At about the same time the highest peaks of the sea bottom were raised to sea level. Wave action eroded loose material from the rising slopes, and this material accumulated in the basins (cf. Winterhalter 1972, p. 54). This erosion and accumulation is still going on because the present land upheaval in this area is about $5 \mathrm{~mm}$. per year (Kääriäinen 1966).

The investigated area can be divided into two different parts on the basis of depth. The western part consists mainly of the Airisto deep. It runs from north to south and is about 40-100 


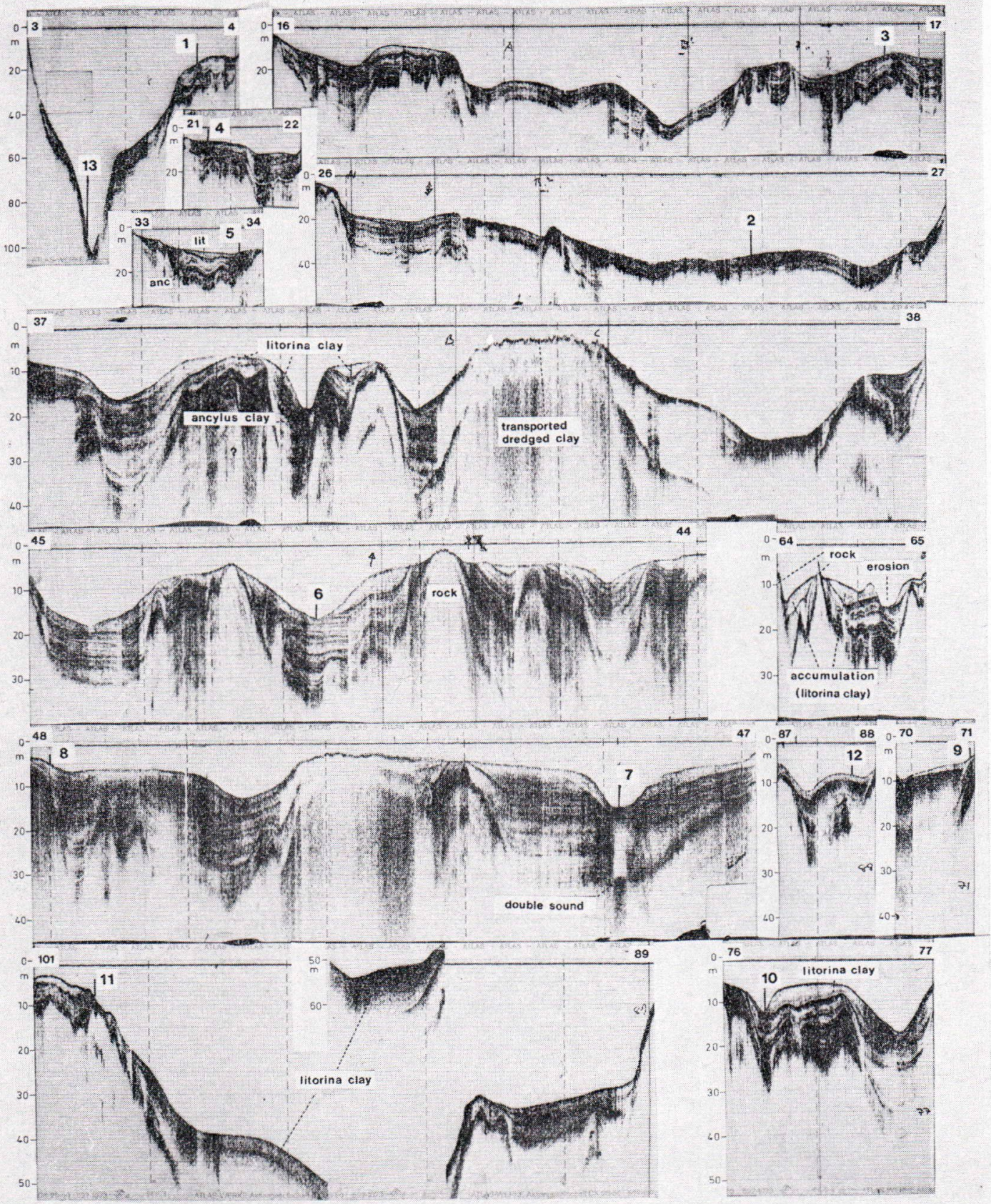

FIG. 2. Echograms and sampling points. 


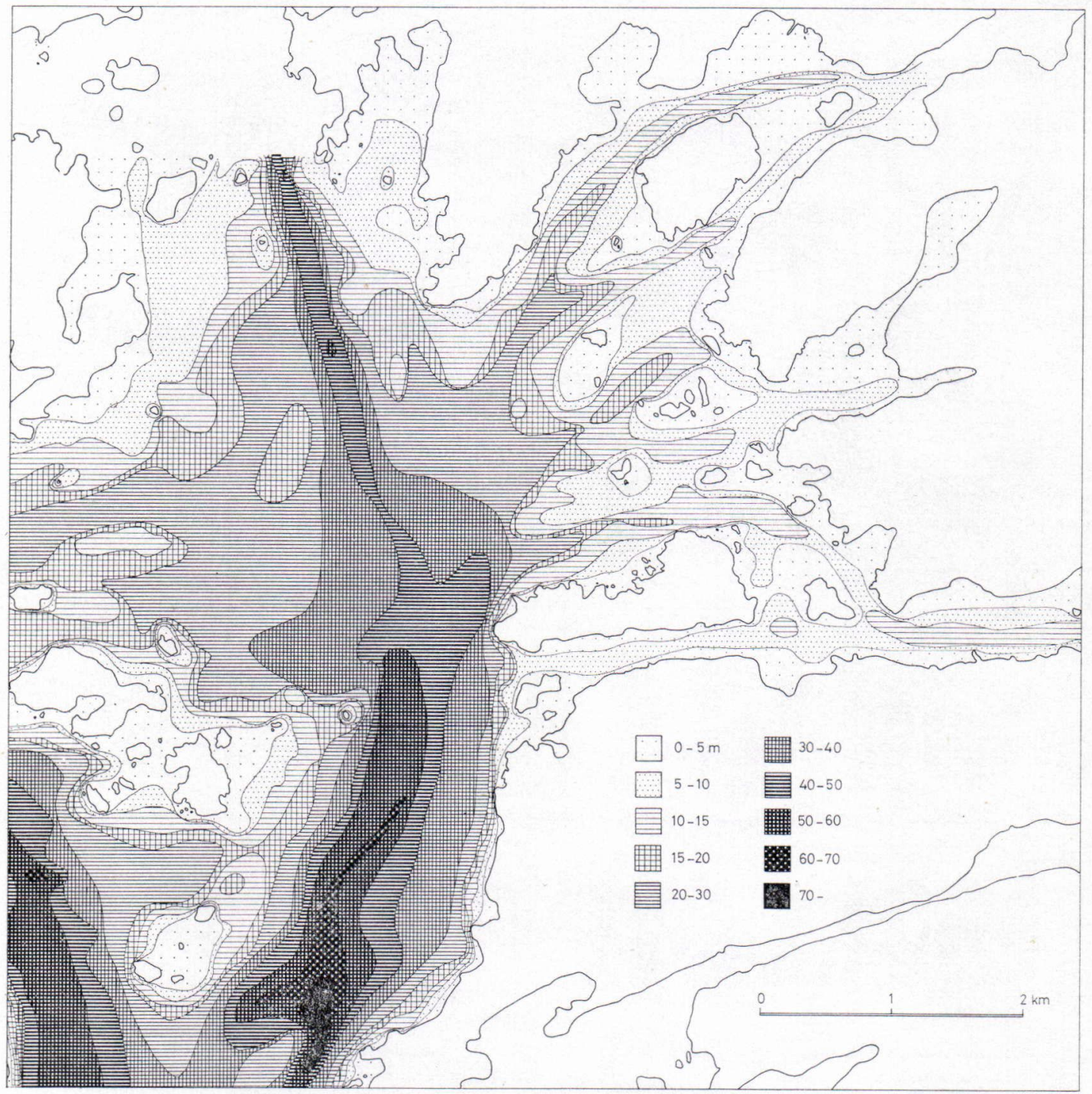

FIG. 3. Bathymetric map. Drawn on the basis of soundings made by the Finnish Board of Navigation and complemented with personal soundings.

m. deep (Fig. 3). It is situated in a large fracture line (Hausen 1960, p. 20). The large stretch of open water in the middle of the area has formed at the junction of many fracture lines following different directions. In the eastern part of the area with its many islands and small straits, the depth of water is usually less than $20 \mathrm{~m}$. The directions of fracture lines are usually E-W and NE-SW.

\section{Collection of material}

The collection of material took place in the summer of 1968. The most important instrument used was an echo-sounder (Atlas Echolot Monograph 58, $30 \mathrm{kHz}$ ). With it it was possible to obtain echograms of sediment as much as $30 \mathrm{~m}$. thick (Fig. 2). With the aid of echograms, 
conclusions were drawn as to the depth of the water and the quantity and quality of soft sediments. The impulse of the echo-sounder did not penetrate hardly at all into bottoms consisting of rock, gravel or sand. As for clays, those containing layers of silt were usually darker in echograms than those consisting mainly of fine clay. The depth of penetration was usually relatively small in clays rich in organic matter (Fig. 2).

On the basis of echo sounding, it was possible to take cores from places of greatest interest. It was a great advantage to be able to follow different layers of sediments with the aid of echograms when determining the quality and location of different layers without the need for a systematic, repeated and deep network of cores. Samples from the layers, which were usually situated well below the bottom surface, could be taken, for instance, from places where currents had prevented later sedimentation, or near rock peaks where layers were usually thin or waves had eroded upper sediments (Fig. 2).

Piston cores from bottom sediments were taken with a sampler from the Archipelago Research Institute of the University of Turku. Cores about three metres long were taken in plastic pipes. The cores were analysed in the laboratory.

The pipes with cores were split and the quality of sediments was determined first by eye. The water and organic matter, texture and diatoms of the core contents were analyzed in turn. The water contents were determined as the loss of weight (per cent of dry weight) when the samples were dried to $105^{\circ} \mathrm{C}$. The amount of organic substance was determined by means of the Walkley-Black method (Morgans 1956, p. 367 385). This method measures the organic carbon content, and the total amount of organic matter is then obtained using a coefficient of 1.8. The results give the organic matter as a percentage of the dry weight of the sample.

To determine the grain size of the clayey sediments, Andreasen's pipette method was used
(Köster 1964, p. 80-82). The advantage of this method is that the weight of the sample may be less than even 10 grams ( $c f$. Lindroos and Niemelä 1969, p. 100). The diatoms were determined using literature (Cleve-Euler 1951-1955, Hustedt 1930, 1961, Mölder and Tynni 1967-1972) and photographs analysed by Dr. R. Tynni. Concentrations of diatoms were obtained by decanting.

\section{Sediments}

The bottom surface of the investigated area consisted almost everywhere of clay containing a greater or smaller proportion of organic matter. Sea iron ore was encountered on a surface of Ancylus clay at least at sample points 5 and 13 (Fig. 4). Rocky bottoms were usually situated at the ends of sounding lines near shores though sometimes they occurred as small peaks in deeper water too (Fig. 2).

In Practically the whole of the investigated area Litorina sediments and older sediments could be distinguished from each other (Fig. 5). In the echograms there was usually a clearlydefined boundary separating the Ancylus and Litorina sediments ( $c f$. Winterhalter 1972, p. 53). In this zone there was usually a thin layer of sediment that seemed coarser than the clay on either side of it. Probably this layer has been formed by wave action during a relatively rapid change in the sea level. The material of this layer originates from surrounding shores; it is thus some kind of shore formation. Sediments above the zone, being deposited in salt water, were in echograms relatively homogeneous but sometimes there was very slight layering, however. The sediments below, being mainly accumulated at the Ancylus stage, appeared from the echograms to be, almost without exception, layered (Fig. 2). The penetration of the impulse of echo sounder was usually better in Ancylus clays than in Litorina clays, and in the latter least in those 

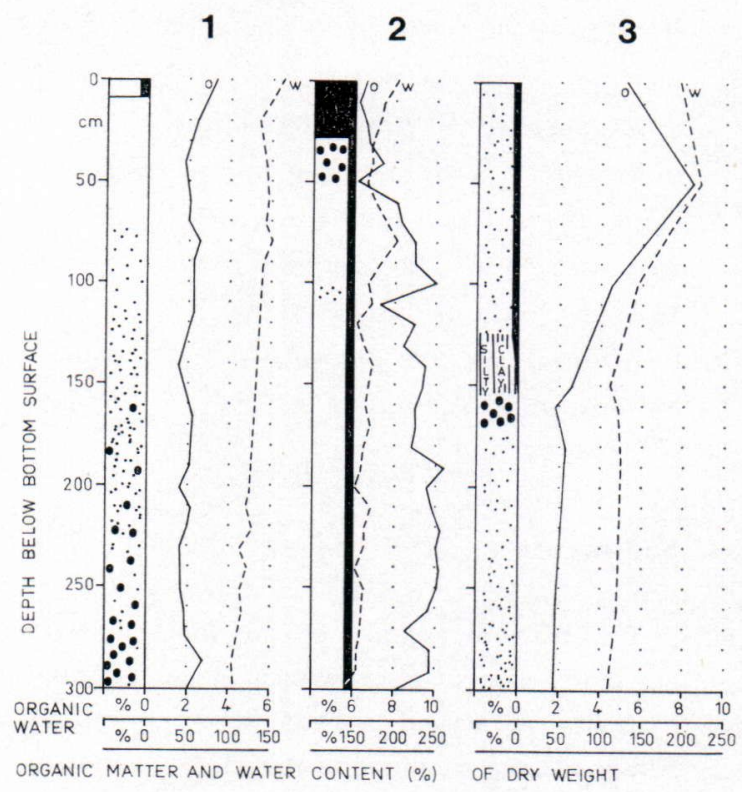

4

5

6
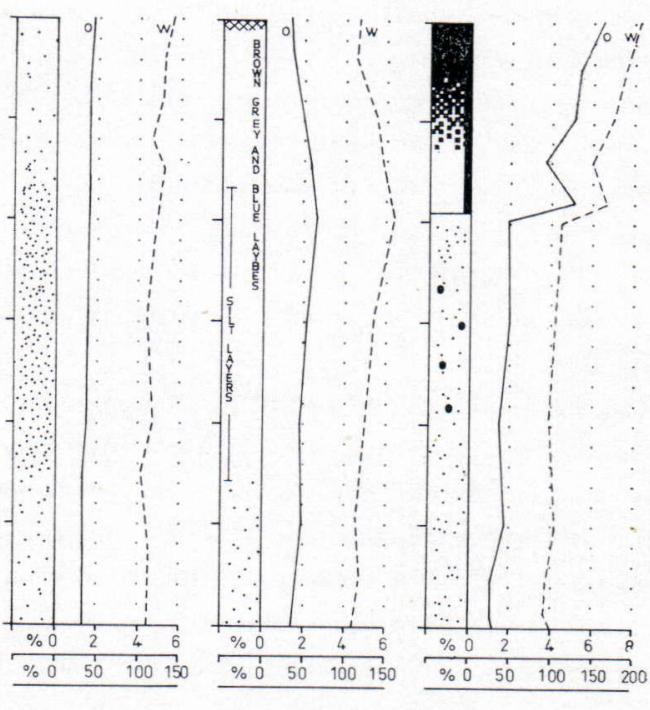

7

8

9

10

11

12
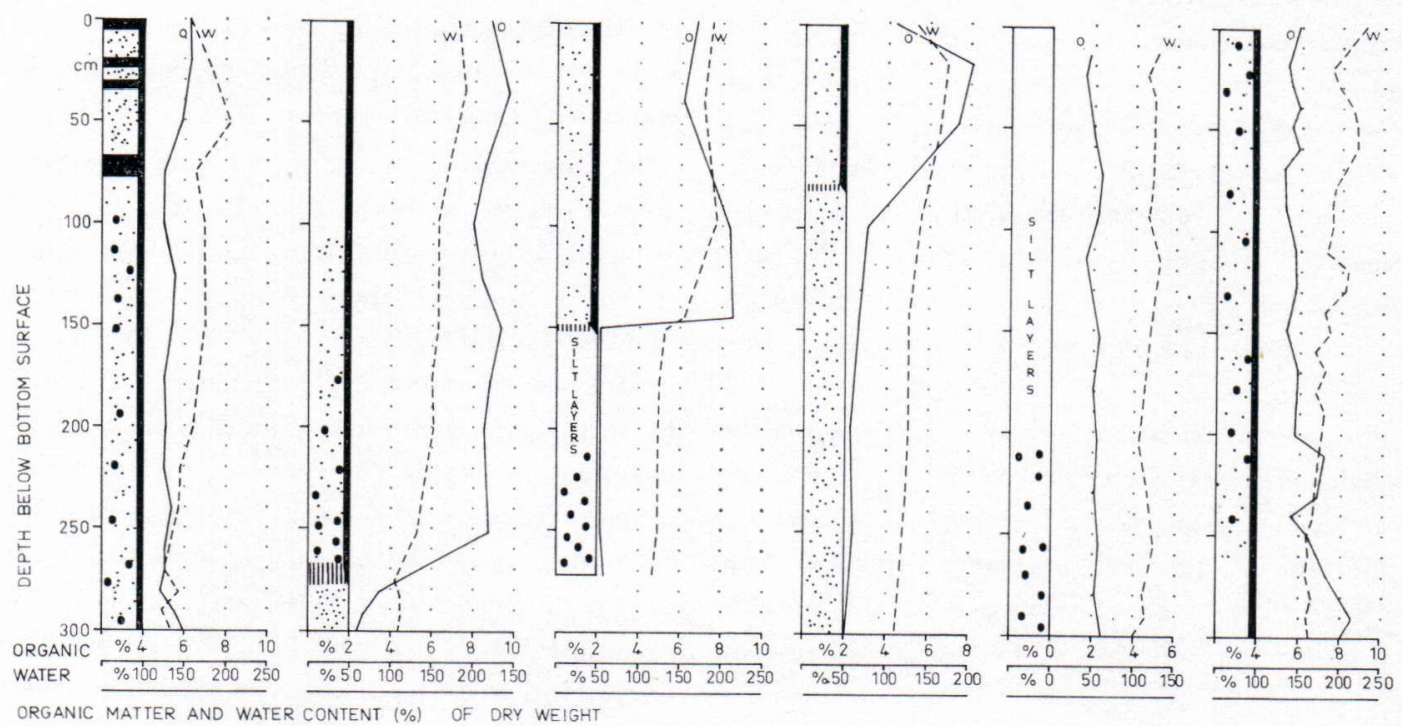

13
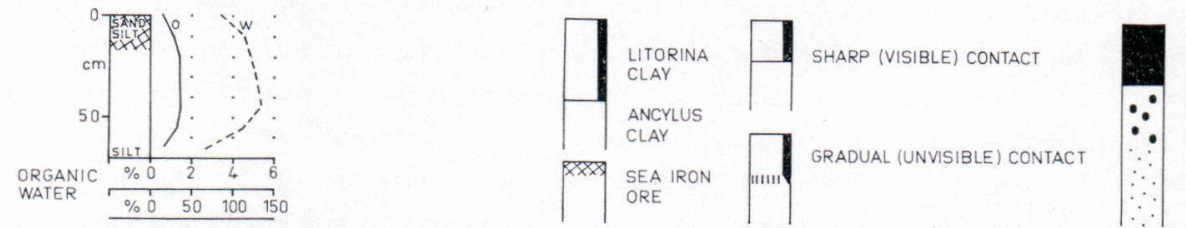

BLACK SULFIDE-CLAY

GREY CLAY WITH BIG BLACK SPOTS

GREY CLAY WITH SMALL BLACK SPOTS

FIG. 4. Samples when fresh, organic matter content and water content. 


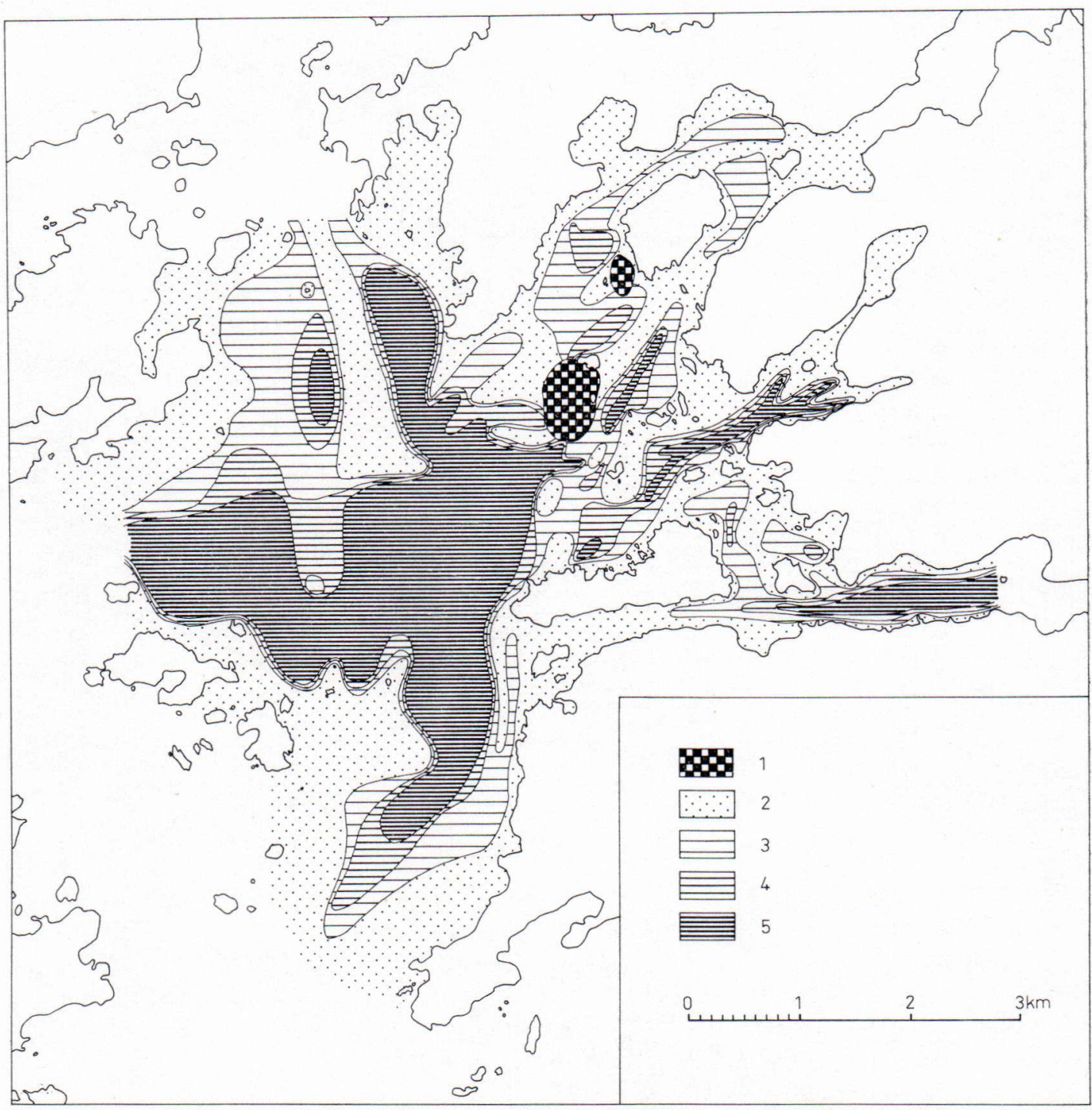

FIG. 5. Sea bottom. $1=$ transported dredged clay, $2=$ Ancylus clay, $3-5=$ Litorina clay: $3=$ less than $3 \mathrm{~m} ., 4=3-6 \mathrm{~m} ., 5=$ more than $6 \mathrm{~m}$.

containing the greatest proportion of organic matter. In these, the factor preventing penetration might have been bubbles of gas in the sediments. The existence of these might also explain the great expansion of some sediments after sampling. This expansion was especially characteristic of cores containing a large proportion of organic matter, for instance, cores 2 and 12 .
Litorina sediments. - Sediments which were deposited in salt water during the Litorina period less than 7000 years ago (Ignatius and Niemistö 1971, p. 78) and which contained abundant organic matter were found at sampling points 1, 2, 3, 6, 7, 8, 9, 10 and 12 (Figs 1, 2 and 4). When fresh it was usually brownish or greenish grey (cf. Ignatius et.al., 1968, p. 131). 


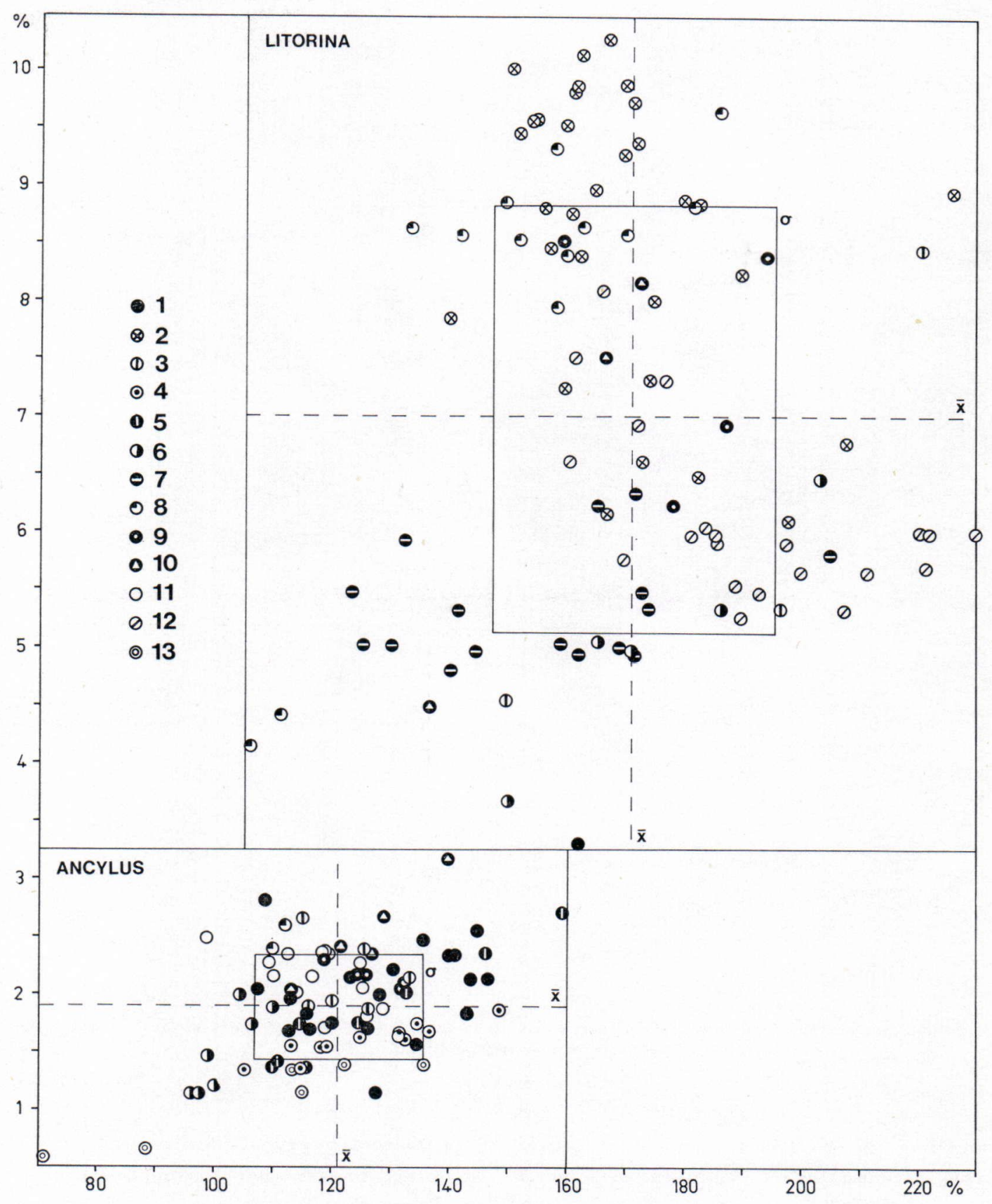

FIG. 6. Contents of organic matter and water in samples. Sampling points $1-13$. $\overline{\mathrm{x}}=$ means, $\sigma=$ standard deviations. 
However, part of the cores consisted of black sulphide clays or there were layers or spots of black clay in grey sediments (Fig. 4, cf. Papunen 1968 , p. 51,53$)$. The organic matter content ranged from $3.3 \%$ to $10.3 \%$ of dry weight. The mean $(\overline{\mathrm{x}})$ was $7.0 \%$ (95 determinations) and the standard deviation $(\sigma) \pm 1.8 \%$ (Fig. 6). According to Lisitsyn (1966, p. $474-475)$ the maximum of organic carbon in the Baltic Sea is about $4 \%$, which corresponds well with the above mean. Lindroos and Niemelä (1969, p. 102) have, in their examination in the HelsinkiHämeenlinna district, obtained values of about $4-10 \%$ for organic matter found in Litorina sediments. These values correspond almost completely to those in this paper.

The water content of Litorina sediments ranged from $106.1 \%$ to $230.1 \%$. The mean ( $\bar{x}$ ) of 104 analyses was $171.4 \%$ and the standard deviation $(\sigma) 24.1 \%$ (Fig. 6).

On the basis of 12 determinations, the grain size of Litorina clays in the examined area would seem to be very uniform (Fig. 7). The percentage of fractions less than $0.002 \mathrm{~mm}$. in diameter ranges from 55 to 75 . According to Gripenberg (1934, p. 217), the maximum value for this fraction in postglacial clays is about $70 \%$ in the Baltic Sea, so that the results are satisfactory.

In Litorina clays the number of diatom species was relatively large (Fig. 8). The boundary between Litorina and Ancylus clays was generally clearly defined, although Ancylus lake species were also present in younger sediments which had been deposited in salt water. The reason for this is the continuing erosion and re-deposition in the area. However, most of the diatoms consisted of flora typical of fresh-brackish or brackish-saline water. The most numerous species found immediately above Ancylus sediments were, in most cores, Epithemia turgida and E.t. var. westermanni. Somewhat higher up the most frequently encountered species were $R h a b$ donema arcuatum, $R$. minutum, Grammatophora oceanica, G. marina and Nitzschia punctata. Typical species in the upper parts of Litorina clays
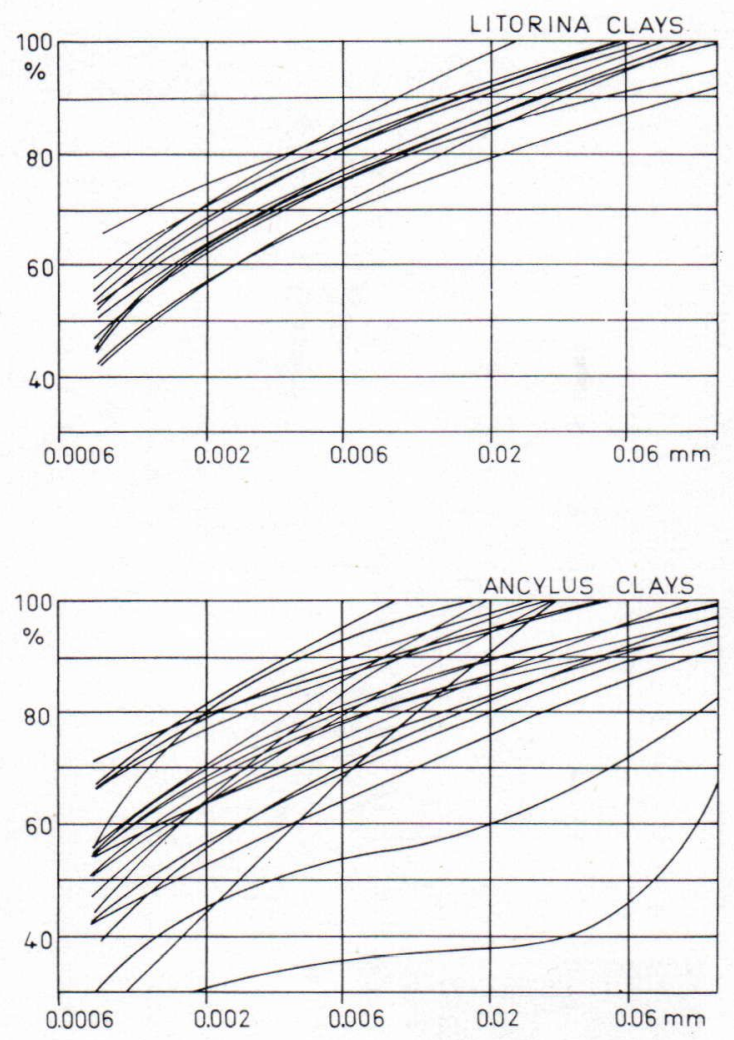

FIG. 7. The grain size of Ancylus and Litorina sediments. Cumulative curves.

were Campylodiscus echeneis, Thalassiosira baltica and Chaetoceros sp. In the youngest clays one of the most numerous species was Coscinodiscus asteromphalus, which is relatively common in this area at present, too.

Ancylus sediments. - Ancylus sediment deposited in fresh water was found at sampling points 1, 3, 4, 5, 6, 8, 9, 10, 11 and 13 (Figs 1, 2 and 4). These clays, which were usually a lighter grey than Litorina clays, also contained numerous spots of black sulphide clay in many places (Fig. 4, cf. Ignatius 1958b, p. 138, Papunen 1968, p. 51). The organic matter content in Ancylus clays varied from $0.7 \%$ to $3.2 \%$ of dry weight. The mean ( $\bar{x}$ ) was $1.9 \%$ (86 determinations) and standard deviation $(\sigma)$ was $\pm 0.5 \%$ (Fig. 6 ).

Reasons for the small amounts of organic 


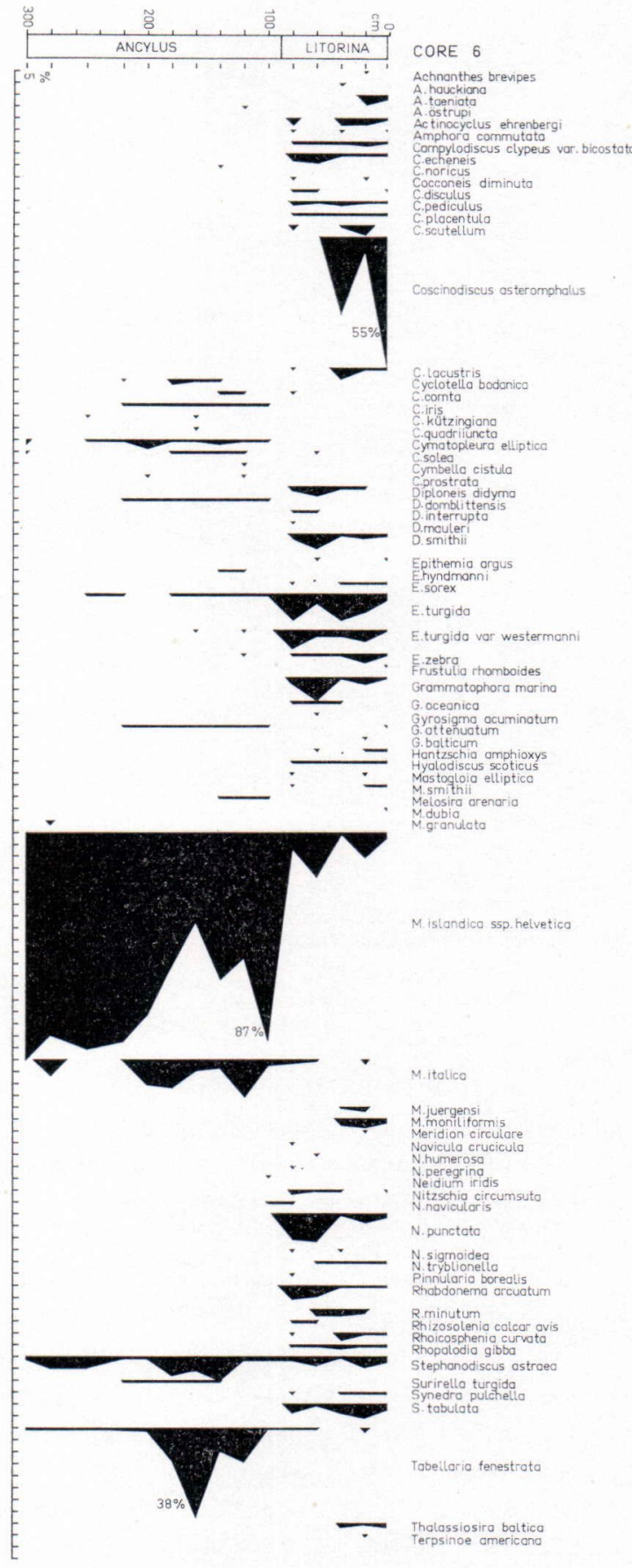

FIG. 8. Diatoms in core 6 as a typical example of diatoms in Ancylus and Litorina sediments in the investigated area. matter may be in part weather conditions at the time of deposition ( $c f$. Ignatius and Niemistö 1971, p. 74), and relatively abundant sedimentation of mineral substances. Coagulation of organic matter and mineral substance does not take place in fresh water, so that currents were able to transport the light organic matter away before deposition on the bottom.

The water content of Ancylus sediments ranged from $70.7 \%$ to $159.1 \%$ of dry weight. The mean $(\overline{\mathrm{x}})$ was $121.1 \%$ (89 determinations) and the standard deviation $(\sigma) \pm 14.4 \%$ (Fig. 6). The 20 measurements made of the grain size of Ancylus sediments showed that there was greater variation than in those of the Litorina stage. The proportion of fractions less than $0.002 \mathrm{~mm}$. in diameter varied from $30 \%$ to $82 \%$ (Fig. 7).

The number of diatom species was relatively small in Ancylus sediments, and it became even smaller in their lower parts (Fig. 8).

The dominant species were Melosira islandica ssp. belvetica, M. italica and Stephanodiscus astraea, the former especially in the oldest Ancylus sediments ( $c f$. Alhonen 1967). In addition to these, the most common species were Tabellaria fenestrata, which at places was rather abundant, and Cymatopleura elliptica.

In echograms of Ancylus sediments there was often a dark layer, sometimes several meters thick (e.g. lines 33-34, 37-38, 44-45 and $76-77$, Fig. 2). It was reached by cores 5, 9 and 11. These cores consisted of clays with numbers of silt layers running through them (Fig. 4). Diatoms were almost entirely absent, and some of them were brackish water species. The sediments in question were probably deposited at the same time as the surrounding sea bottom rose, causing the sediments to be subjected to wave action. These re-deposited sediments consist of material, largely postglacial in origin situated nearby. The large proportion of fine fractions $(70-82 \%$ less than $0.002 \mathrm{~mm}$. in diameter, $c f$. Gripenberg 1934, p. 217) also supports this hypothesis. 


\section{Conclusions}

The samples taken of Ancylus and Litorina sediments were usually clearly distinguishable on the basis of their organic matter content and diatoms. The means of water contents were also different, although determining the type of sediments on the basis of this single factor was usually impossible. As for grain sizes, the results of analyses gave reason to believe that Litorina sediments in the investigated area are more uniform than the Ancylus sediments in this respect.

When fresh, Litorina clays are usually greenish or brownish grey, sometimes dark grey or quite black, but Ancylus clays are often light. However, the colour of sediments is not always a sure method of identifying sediments. Black spots of sulphide clay were seen in both types of sediments. When the clay was dried, these differences in colour were no longer visible (Fig. 4, cf. Papunen 1968, p. 53).

The correlation coefficient ( $r$ ) between the organic matter content and water was, $0.695^{* * *}$ for all samples $(n=182)$. That of Ancylus sediments was $+0.422^{* *}(\mathrm{n}=85)$ and of Litorina sediments $-0.004(n=97)$. On the basis of these values it would seem that changes in organic matter and water content in Ancylus sediments are more closely related than is the case with Litorina sediments. Also the variation of these two factors was smaller in Ancylus sediments than in Litorina sediments (Fig. 6).

The most effective area of deposition at present is in the middle of the investigated area. At the bottom of this stretch of open sea there are scores of metres of postglacial sediments. Sedimentation during the Litorina stage was in places more than $2 \mathrm{~mm}$. per year (Figs 2 and 5, cf. Ignatius 1958a, p. 39, Winterhalter 1972 , p. 53).

Areas of accumulation and erosion were determined roughly according to the kind of sediments forming the bottom surface. Bottoms consisting of Litorina sediments were classified as areas of accumulation, and those of Ancylus sediments as areas of erosion. The thickness of Litorina sediments was considered as indicative of the rate of accumulation.

Erosion or non-deposition usually prevailed in those areas, where the water was less than 15-20 m. deep (Figs 3 and 5). In some places, however, these areas were found even in the deepest parts of the whole investigated area. The most important eroding factor in areas of shallow water is wave action ( $c f$. Winterhalter 1972 , p. 48 - 50). In the deepest areas, however, it is currents, that erode the bottom or at least prevent sedimentation.

Acknowledgements - Mr. Tapani Juusti and Mr. Paavo Tulkki from the Archipelago Research Institute, University of Turku, helped the author in his field investigations. Dr. Risto Tynni helped him, in determining the diatoms. Mrs. Varpu Välimäki and Mrs. Leena Kiiskilä from the Departement of Geography, University of Turku, drew the figures in their final form. Professor Martti Salmi, Dr. Pentti Alhonen and Dr. Matti Seppälä read the manuscript and made many useful suggestions. Mr. Christopher Grapes has revised the language of this work. The author has received financial support from the National Research Council for Natural Sciences. To all these persons and institutions he wishes to express his sincere thanks. 


\section{REFERENCES}

Alhonen, Pentti (1967) Palaeolimnological investigations of three inland lakes in South-Western Finland. Acta Botanica Fennica 76, 1-59.

Bordowskry, O. K. (1965) Accumulation and transformation of organic substance in marine sediments. Marine Geology 3, 1/2, 3-114.

Cleve-Euler, Astrid (1951-1955) Die Diatomeen von Schweden und Finnland. I-V. Kungliga Svenska Vetenskapsakademiens Handlingar 4. Ser., 2:1 (1951), 3:3 (1952), 4: 1,5 (1953) 5:4 (1955).

GripenberG, Stina (1934) A study of the sediments of the north Baltic and adjoining seas. Fennia 60:3, $1-231$.

Hausen, Hans (1960) Grunddragen av sydvästra skärgårdens frakturmönster. Atlas över Skärgårds-Finland, Text, 19-20. Helsinki.

Hustedt, Friedrich (1930) Die Süsswasser-Flora Mitteleuropas, 1-467. Jena.

- (1961) Kieselalgen, 1-64. Stuttgart.

Hyчppä, E. (1966) The late-Quartenary land uplift in the Baltic sphere and the relation diagram of the raised and tilted shore levels. Ann. Acad. Sci. Fennicae, A III, 90, 153-168.

I GNATIUS, HEIK KI (1958 a) Itämeren pohjan tutkimuksesta Vuoriteollisuus-Berghanteringen 2, 37-41.

- $(1958 \mathrm{~b})$ On the rate of sedimentation in the Baltic Sea. Comt. Rend. Soc. Geol. Finlande 30, 135-144.

-, Kukkonen, E., Winterhalter, B. (1968) Notes on a pyritic zone in upper Ancylus sediments from the Bothnian Sea. Bull. Geol. Soc. Finland 40, 131134.

- and Niemistö, L. (1971) Itämeren sedimentit ja sedimentaatio. Luonnon Tutkija 75 N:o 3-4, 72-80.

_ , -, Vorpio, A. (1971) Variations of redox conditions in the recent sediments of the Gotland deep. Geologi 3, $43-47$.
KäÄRIÄINEN, E. (1966) Land uplift in Finland computed with the aid of precise levellings. Ann. Acad. Sci. Fennicae, A III, 90, 187-190.

Köster, Erhard (1964) Granulometrische und morphometrische Messmethoden an Mineralkörnern, Steinen und sonstigen Stoffen. Stuttgart.

Lindroos, P., Niemelä, J. (1969) Savitutkimuksia Helsingin ja Hämeenlinnan välisellä alueella. Geologi 7, 97-104.

Lisitsyn, A. P. (1966) Recent sedimentation in the Bering Sea. Israel Program for Scientific Translations, 1-614. Jerusalem 1969.

Morgans, J. F. C. (1956) Notes on the analysis of shallow water soft substrata. J. Anim. Ecol. 25, 367-387.

Mölder, K., Tynni, R. (1966) Diatomeen in Plankton bei der Stadt Helsinki und in das Stromschnelle Putaankoski im Kirchspiel Askola, Südfinnland, im Jahre 1964. Ann. Botanici Fennici 3, 265-285.

—, -, (1967-1972) Über Finnlands Rezente und Subfossile Diatomeen I-VI. Comp. Rend. Soc. Geol. Finlande XXXIX, 199-217 (1967), Bull. Geol. Soc. Finland 40, 151-170 (1968), 41, 235-251 (1969), 42, $129-144$ (1970), 43, 203-220 (1971), 44, 141-149 (1972).

Papunen, Heik ki (1968) On the sulfides in the sediments of the Bothnian Sea. Bull. Geol. Soc. Finland 40, 51 57.

Winterhalter, Boris (1972) On the geology of the Bothnian Sea, an epeiric sea that has undergone Pleistocene glaciation. Geological Survey of Finland, Bulletin 258, 1-66.

Manuscript received, January 9, 1973. 